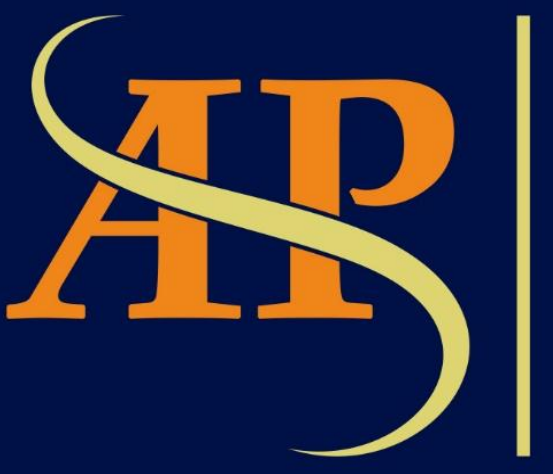

JURNAL

ASIA

PACIFIC

STUDIES

Journal of International Relations Study Program Faculty of Social and Political Sciences

Universitas Kristen Indonesia

Volume 3 | Number 1 | January - June 2019 


\title{
GEOPOLITIK CINA DAN JEPANG DI ASIA TIMUR: SENGKETA KEPULAUAN DIAOYU/SENKAKU
}

\author{
${ }^{1}$ Destrina Christianty, ${ }^{2}$ Geriel Jonathan, ${ }^{3}$ Lamtiur Simamora, ${ }^{4}$ Ribka Helena, ${ }^{5}$ Ruth Diana Rebecca, \\ ${ }^{6}$ Sathya Reysha Wacanno \\ ${ }_{1,2,3,4,5,6}$ Program Studi Ilmu Hubungan Internasional, Fakultas Ilmu Sosial dan Ilmu Politik, Universitas Kristen \\ Indonesia, Jl. Mayjen Sutoyo No.2, RT.9/RW.6, Cawang, Kec. Kramat Jati, Jakarta Timur \\ 1destrina36@gmail.com, 29 gerieljonathan@gmail.com, ${ }^{3}$ lamtiursimamora988@gmail.com, \\ ${ }^{4}$ ribkahelena22@gmailc.om ${ }^{5}$ ruthdiana.r@gmail.com; ${ }^{6}$ sthreysha@gmail.com
}

\begin{abstract}
Uninhabited islands known as Senkaku for Japan and Diaoyu for China are about $170 \mathrm{~km}$ from Okinawa and Taiwan, and $380 \mathrm{~km}$ from mainland China. Both parties claim ownership of each other from the island, based on historical evidence and agreements. However, differences in interpretation of historical evidence and agreements make disputes between China and Japan about ownership rights of these. The position of a very strategic island in the Pacific Ocean and in 1969 was stated, the islands might have oil and gas reserves, which made the People's Republic of China claim the islands only two years later. Both of these complicate agreements in terms of ownership of the island.
\end{abstract}

Keywords: Dispute, Claim, Ownership

\begin{abstract}
Abstrak
Pulau-pulau tak berpenghuni yang dikenal sebagai Senkaku untuk Jepang dan Diaoyu untuk Cina terletak sekitar $170 \mathrm{~km}$ dari Okinawa dan Taiwan, dan $380 \mathrm{~km}$ dari daratan Cina. Kedua pihak saling mengklaim kepemilikan dari pulau tersebut, berdasarkan pada bukti sejarah dan perjanjian. Namun, perbedaan interpretasi bukti sejarah dan perjanjian menjadikan perselisihan antara Cina dan Jepang tentang hak kepemilikan dari pula tersebut. Posisi pulau yang sangat strategis di Samudera Pasifik dan pada tahun 1969 AS mengungkapkan, bahwa pulau-pulau itu mungkin memiliki cadangan minyak dan gas yang membuat Republik Rakyat Tiongkok mengklaim pulaupulau itu hanya dua tahun kemudian. Kedua hal tersebut mempersulit dalam pencapaian kesepakatan dalam hal kepemilikan dari pulau tersebut.
\end{abstract}

Kata Kunci: Sengketa, Klaim, Kepemilikan 


\section{Pendahuluan}

\subsection{Latar Belakang}

Diaoyu/Senkaku merupakan kepulauan yang terletak $170 \mathrm{~km}$ dari Taiwan, $330 \mathrm{~km}$ dari Cina, $170 \mathrm{~km}$ dari Ishigaki (Jepang) dan $410 \mathrm{~km}$ dari Okinawa (Jepang) di Laut Cina Timur. (Affairs 2013) Kepulauan tersebut merupakan delapan pulau dengan total luas wilayah sebesar $6,3 \mathrm{~km}^{2}$ yang terdiri atas Tiga pulau dari kepulauan tersebut adalah batuan tandus dan lima lainnya merupakan pulau kecil. Kedelapan pulau tersebut adalah Uotsurijima, Kitakojima, Minamikojima, Kuba, Taisho, Okinokitaiwa, Okinominamiiwa, dan Tobise (Pan 2007).

Perbedaan interpretasi bukti sejarah dan perjanjian menjadikan perselisihan antara Cina dan Jepang tentang hak kepemilikan dari kepualuan tersebut. Posisi kepulauan yang sangat strategis di Samudera Pasifik dan pada tahun 1969 ketika Amerika Serikat mengungkapkan, bahwa pulau-pulau itu mungkin memiliki cadangan minyak dan gas, yang membuat Republik Rakyat Tiongkok mengklaim pulau-pulau itu hanya dua tahun kemudian. Kedua hal tersebut mempersulit dalam pencapaian kesepakatan dalam hal kepemilikan dari pulau tersebut yang menimbulkan ketegangan antaran kedua negara tersebut yang memberi dampak terhadap geopolitik masing - masing pihak.

Sejak tahun 1885, survei Kepulauan Senkaku dilakukan secara menyeluruh oleh Pemerintah Jepang oleh agen-agen Prefektur Okinawa. Melalui survei ini, menunjukan bahwa Kepulauan Senkaku tidak berpenghuni dan tidak berada di bawah kendali Dinasti Qing Cina. Berdasarkan konfirmasi ini, pemerintah Jepang membuat Keputusan Kabinet pada tanggal 14 Januari 1895 yang menandakan bahwa Kepulauan Senkaku secara resmi masuk ke dalam wilayah Jepang ". Pada dasarnya pemerintah Jepang berpendapat bahwa pada tahun 1895, pulau-pulau itu adalah terra nullius, yaitu, tanah tanpa pemilik, ketika Jepang memutuskan untuk menduduki mereka (Ivy Lee 2012).

Setelah menggunakan diplomasi kapal perang untuk memaksa Korea membuka pelabuhannya pada tahun 1876, dan menganeksasi Kerajaan Ryukyu pada tahun 1879, Jepang mengalihkan perhatiannya ke pulau-pulau yang terletak di antara Okinawa dan Taiwan. Dokumen-dokumen yang dideklasifikasi pada 1950-an termasuk laporan tertanggal 22 September 1885 dari Okinawa Prefectural Magistrate yang atas perintah rahasia dari Menteri Dalam Negeri Jepang, menyelidiki tiga pulau, Uotsuri-jima (Diaoyu Dao), Kuba-jima (Huangwei Yu), dan Taisho-jima (Chiwei Yu) (Ivy Lee 2012).

Hakim Okinawa mencatat dalam laporan tersebut bahwa menggabungkan, dan juga menempatkan penanda dik pulau-pulau tersebut tidak akan menimbulkan masalah. Namun, ia juga mencatat bahwa ada kemungkinan bahwa pulau-pulau ini mungkin sama dengan yang sudah dicatat dalam Catatan Misi Zhongshan, yang digunakan sebagai alat bantu navigasi oleh utusan Qing ke Kerajaan Ryukyu, perincian yang diketahui oleh dinasti Qing. Dia menyimpulkan bahwa: "perlu dikhawatirkan apakah tepat untuk menempatkan penanda nasional di pulau-pulau ini segera setelah penyeledikan kami...".

Mengabaikan peringatan Hakim, Menteri Dalam Negeri Jepang pada saat itu menyerahkan petisi ke Dewan Agung Negara untuk memasang penanda nasional. Mengakui bahwa pulau-pulau itu mungkin memiliki hubungan (penekanan ditambahkan) dengan Cina, ia menulis: "...meskipun pulau-pulau yang disebutkan di atas sama dengan yang ditemukan di Catatan Misi Zhongshan, mereka hanya digunakan untuk menentukan arah selama navigasi, dan tidak ada jejak bukti bahwa pulau-pulau itu milik Cina ... ". Namun, ketika Menteri Luar Negeri diminta pendapatnya tentang proyek yang diusulkan, ia mencatat bahwa surat kabar Cina sudah penuh dengan laporan kegiatan Tokyo di pulau-pulau dan kemungkinan niatnya 
untuk menduduki pulau-pulau ini yang dimiliki Cina. Oleh karena itu, ia memperingatkan bahwa menempatkan spidol nasional di pulau-pulau hanya akan membangkitkan kecurigaan Cina terhadap Jepang dan bahwa "... itu harus menunggu waktu yang lebih tepat." Dia lebih lanjut mendesak Menteri Dalam Negeri untuk menahan diri dari menerbitkan kegiatan investigasi di pulau-pulau di Berita Resmi atau surat kabar (Ivy Lee 2012).

Cina mengklaim memiliki peta dan dokumen yang berasal dari abad ke 16 dan 17 yang menunjukkan pulau-pulau itu sebagai bagian dari garis pantai pertahanan Tiongkok dan menjadi tempat pendaratan bagi para misionaris Tiongkok. Dan menyatakan bahwa pulaupulau tersebut secara historis merupakan bagian dari Taiwan dan karena itu awalnya Cina memiliki kedaulatan atas pulau-pulau tersebut. Lebih lanjut, Cina berpendapat bahwa mereka berkewajiban untuk melepaskan kedaulatan atas pulau-pulau hanya setelah kekalahan dalam perang Tiongkok-Jepang tahun 1894/1895.

Perjanjian Shimonoseki yang ditandatangani setelah kekalahan Cina pada tahun 1895 tidak secara khusus menyebutkan Senkaku / Diaoyu. Bagi Cina, perjanjian itu berarti bahwa Jepang memperoleh kendali atas wilayah Taiwan dan menggunakan kemenangannya dalam perang untuk mengklaim pulau-pulau tersebut. Oleh karena itu, Cina berpendapat bahwa pulau Diaoyu harus dikembalikan ke Cina. Karena, Cina telah mengambil kembali kedaulatannya atas Taiwan setelah Perang Dunia II.

Setelah kekalahan Jepang pada Perang Dunia II, Jepang menyerah tanpa syarat. Pada Perjanjian San Francisco tahun 1951, Perjanjian tersebut menyatakan bahwa Jepang akan diwakilkan oleh Amerika Serikat dan AS sebagai satu-satunya otoritas admintrasi tersebut. Perjanjian itu tidak secara khusus menyebutkan Senkaku / Diaoyu tetapi tampaknya pulaupulau itu ditempatkan di bawah perwalian dengan ditutup di daerah yang dikenal sebagai Nansei Shoto (selatan $29^{\circ} \mathrm{N}$ ). Perjanjian tersebut berarti menyatakan AS memiliki hak untuk menggunakan semua kekuasaan administrasi, perundang-undangan dan yurisdiksi atas wilayah dan penduduk pulau-pulau ini, termasuk perairan teritorial mereka. Ketika, Jepang berada dibawah pemerintahan Amerika Serikat, Cina terlihat melunak terhadap persoalan sengketa pulau tersebut (Garlicki, The Senkaku/Diaoyu Islands Dispute: History and Currents Developments 2014).

Pada tahun 1969, setelah perwakilan PBB menerbitkan hasil penelitian bahwa kemungkinan Pulau Diaoyu/Senkaku memiliki cadangan minyak dan gas memicu reaksi dari Cina dan Jepang tentang kepemilikan dari wilayah tersebut. Dan pada tahun 1972, Amerika Serikat telah mengembalikan seluruh wilayah Jepang. Dan hingga saat ini, kepemilikan pulau tersebut berada dibawah pemerintahan Jepang.

\subsection{Rumusan Masalah}

Rumusan masalah dari penelitian ini adalah: Bagaimana geopolitik Cina dan Jepang dalam sengketa Kepulauan Diayou/Senkaku?

\section{Kajian Pustaka dan Kerangka Pemikiran}

Menurut Sempa dalam bukunya Geopolitics, Frm the Cold War to the $21^{\text {st }}$ Century, Geopolitik berbicara tentang interaksi antara negara dan kekaisaran dalam pengaturan geografis tertentu. Geografi adalah faktor paling mendasar dalam politik internasional karena merupakan yang unsur paling permanen. Geografi suatu negara — posisinya di wilayah geografis dan di dunia secara keseluruhan - memberikan peluang kepada negara, dan memberi batasan pada negara. Karena alasan itu, geografi juga mengkondisikan perspektif para pemimpin atau penguasa suatu negara dan, dengan demikian, mempengaruhi 
pengambilan keputusan mereka dalam hal kebijakan luar negeri. Sepanjang sejarah, geografi telah memengaruhi orientasi geopolitik negara-negara ke arah kekuatan darat ataupun laut. Lokasi pulau atau kepulauan mungkin akan mengarahkan suatu negara ke laut, sedangkan lokasi benua kemungkinan akan mengarahkan suatu negara ke daratan. Orientasi laut atau darat suatu negara belum tentu absolut. Suatu negara yang berorientasi laut mungkin dapat memproyeksikan kekuatan di darat, dan suatu negara yang berorientasi darat mungkin membawa ke laut (Sempa 2002).

Peterson dalam bukunya The World Island: Eurasian Geopolitics and the Fate of the West mengutip kutipan Mackinder dari makalah pertamanya yaitu "On the Scope and Methods of Geography" yang ditulis tahun 1887 yang disebut "dokumen klasik dalam sejarah perkembangan geografi Inggris". Dalam makalah itu, Mackinder berpendapat bahwa geografi politik yang bersifat "rasional" dibangun di atas dan di samping geografi fisik." Di manamana" lanjutnya pertanyaan politik akan tergantung pada hasil penyelidikan secara fisik. "Fungsi geografi politik" adalah untuk "melacak interaksi antara manusia dan manusia dengan lingkungannya". Lingkungan itu, menurut Mackinder, termasuk" konfigurasi permukaan bumi, kondisi iklim dan cuaca, dan ada tidaknya sumber daya alam" yang dimiliki oleh sebuah negara (Petersen 2011).

Mackinder mengakui dominasi seapower sepanjang sejarah negara - negara, tetapi ia selalu berusaha menjelaskannya dengan menekankan pada landpower. Dia mampu menunjukkan dengan meyakinkan bagaimana seapower secara mendasar merupakan masalah pangkalan yang tepat, menjaganya agar produktif dan aman.

Menurut John Agnew, konsep "place" menurutnya terbagi atas tiga elemen penting yang berpengaruh terhadap geopolitik sebuah negara yaitu yang pertama locale, dimana ada pengaturan (baik informal atau institusional) di mana hubungan sosial dibentuk, yang kedua location, terbentuknya hubungan antara satu tempat dengan tempat yang lainnya, dan yang terakhir sense of place, orientasi subjektif yang ditimbulkan ketika menetap di suatu tempat (Agnew 1987).

Dari penjelasan Mackinder terkait dengan pentingnya geografi bagi sebuah negara, bisa dilihat pada sengketa Kepulauan Diaoyu/Senkaku dimana letak geografi yang strategis berada antara Jepang dan Cina membuatnya menjadi poros utama perebutan klaim atas kepulauan ini. Geografi dari Kepulauan Diaoyu/Senkaku kemudian menimbulkan ketegangan antara Cina dan Jepang yang berdampak terhadap politik kedua negara. Cina dan Jepang berusaha untuk menunjukan power mereka atas klaim kepulauan tersebut. Tak heran, jika hubungan kedua negara menjadi renggang dan adanya usaha saling klaim atas kepemilikan dari kepulauan Diaoyu/Senkaku. Dominasi atas seapower terhadap kepulauan ini, terlihat jelas dengan adanya patroli laut yang dilakukan oleh masing - masing pihak dengan menggunakan kapal - kapal canggih dengan penggunaan radar jarak jauh yang memantau pergerakan masing - masing negara. Untuk landpower sendiri, kepulauan Diaoyu/Senkaku memiliki banyak cadangan sumber daya alam dibuktikan dengan adanya laporan dari Perserikatan Bangsa - Bangsa tentang jumlah cadangan sumber daya alam yang dimiliki, yang kemudian semakin meyakinkan Cina dan Jepang untuk memiliki hak legal ata kepemilikan kepulauan ini.

Sense of place yang dirasakan oleh Cina dan Jepang terhadap Kepulauan Diaoyu/Senakaku sudah dirasakan dari dahulu ketika bagaiman Cina mengklaim kepulauan ini berdasarkan garis historis sejak Dinasti Qing yang digunakan sebagai jalur navigasi. Kemudian, Jepang meyakini bahwa kepemilikan pulau - pulau tersebut adalah terra nulluis dan dengan adanya perjanjian - perjanjian yang dilakukan oleh Jepang and Amerika Serikat setelah Perang Dunia II. 

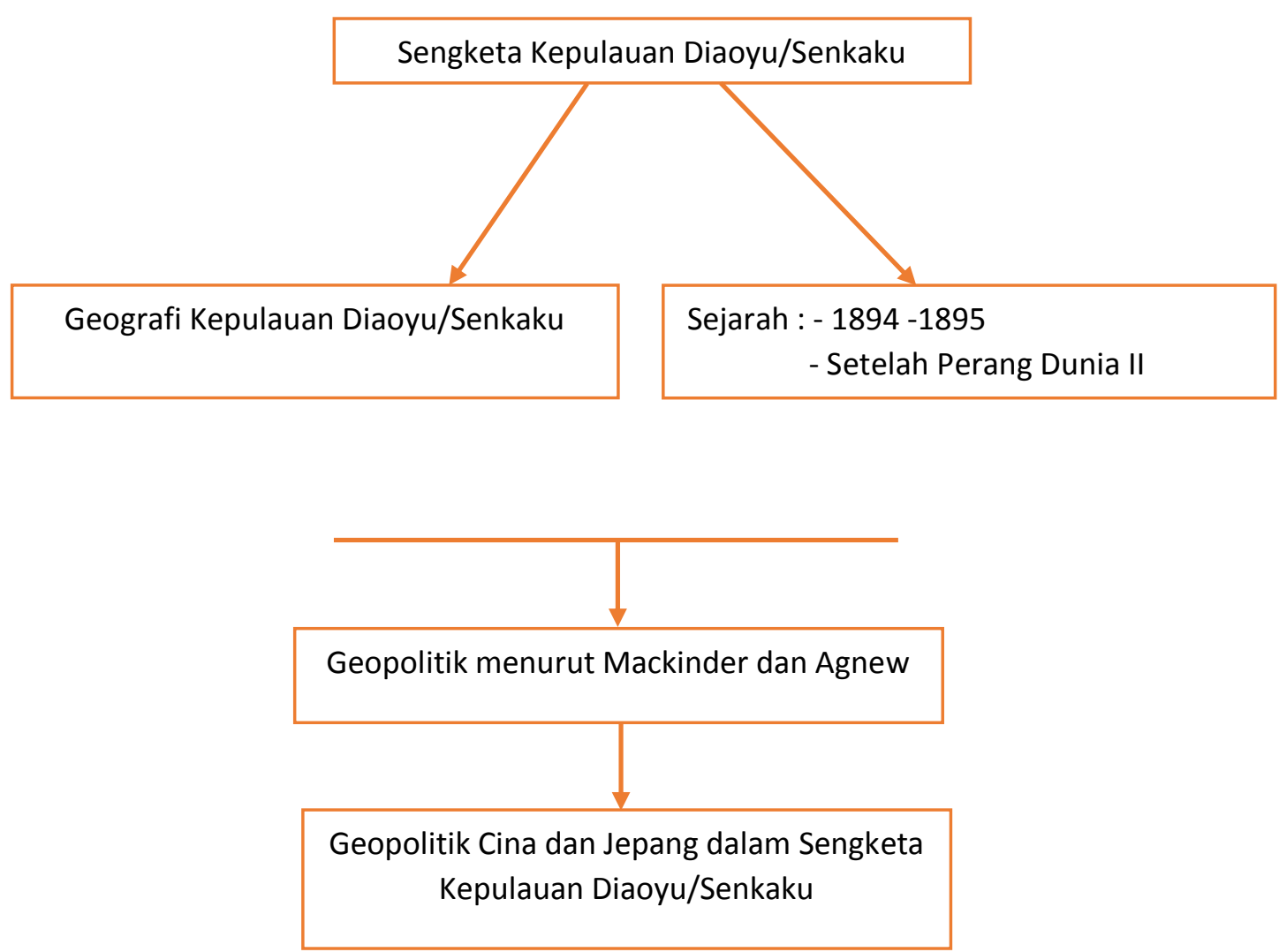

\section{Pembahasan}

Kepulauan Diaoyu atau Senkaku merupakan sebuah kepulauan yang berada di LautTiongkok Timur, tepatnya berada pada sebelah Timur Republik Rakyat Tiongkok,sebelah selatan Jepang, dan sebelah utara Republik Tiongkok atau Taiwan.Berada pada garis

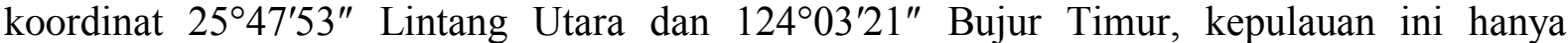
memiliki luas $7 \mathrm{~km}^{2}$. Kepulauan Diaoyu atau Senkaku terdiri dari lima pulau besar dan tiga karang, dari lima pulau dan tiga karang yang ada di Kepulauan Diaoyu/Senkaku tersebut, tidak satu pun dari semua itu yang berpenghuni pada tahun 2010 meskipun pada awal abad ke-20 sempat berpenghuni sekitar 200 jiwa yang merupakanpekerja untuk sebuah perusahan ikan makarel.

5 pulau besar yang berada di Kepulauan Diaoyu/Senkaku: Diaoyu Dao (釣魚島) atau Uotsuri Jima (釣魚島), Chiwei Yu (赤尾嶼) atau Taisho Jima (大正島), Huangwei Yu (黃尾 嶼) atau Kuba Jima (久場島), Bei Xiaodao (北小島) atau Kita Kojima (北小島) dan juga Nan Xiaodao (南小島) atau Minami Kojima (南小島). Selain itu, terdapat 3 karang yaitu Bei Yan (北岩) atau Kitaiwa (北岩), Nan Yan (南岩) atau Minamiiwa (南岩), Fei Jiao Yan (飛礁岩) atau Tobise (飛瀬). Dalam sengketanya terhadap Kepulauan Diaoyu atau Senkaku, China dan Jepang memiliki klaim sejarah kepemilikan yang jauh berbeda. Dimana klaim-klaim tersebut memiliki pendekatan-pendekatan yang berfungsi sebagai dasar pendukung klaim keduanya.

Cina mengklaim Kepulauan Diaoyu berdasarkan penemuan sejarah, yang dimasukkan ke dalam perimeter pertahanan oleh permbajak Jepang selama dinasti Ming, dan penggabungannya ke Cina sebagai bagian dari Taiwan dalam dinasti Qing. Jepang, di sisi lain, mengklaim telah memasukkan pulau-pulau ini sebagai terra nullius pada Januari 1895, sementara Cina menyatakan mereka diserahkan ke Jepang pada akhir Perang Sino-Jepang 
pertama pada bulan April di tahun yang sama. Dari tahun 1952 hingga 1972, Amerika Serikat mengelolah kepulauan dan kelompok pulau lainnya di bawah perwalian Perserikatan BangsaBangsa sesuai dengan ketentuan Perjanjian Perdamaian San Francisco.

Pada tahun 1972 sesuai dengan Perjanjian Reversi Okinawa, Amerika Serikat mengalihkan kendali administratif pulau-pulau ini kembali ke Jepang atas protes keras dari Cina. Atas desakan Jepang, Amerika Serikat ikut serta dalam perselisihan dengan menyatakan setiap serangan terhadap Senkaku setara dengan serangan terhadap Amerika Serikat yang didasarkan pada Pasal 5 Perjanjian Keamanan Bersama Amerika Serika-Jepang tahun 1960. Karena Cina bukan penandatangan San Fransisco Peace Treaty dan tidak terikat oleh ketentuannya, Cina terus menganggap pulau-pulau itu sebagai miliknya, berdasarkan bukti Deklarasi Kairo dan Potsdam dan persyaratan penyerahan yang ditandatangani Jepang pada tahun 1945.

Persaingan klaim atas Kepulauan Diaoyu/Senkaku menjadi semakin rumit. Situasi ini diperumit dengan ditemukannya cadangan gas dan minyak pada akhir 1960-an, sehingga lebih sulit untuk mengurai benang jalinan irredentisme, dan juga sengketa batas-batas Zona Ekonomi Wilayah dan Eksklusif, dan yang lainnya adalah pertimbangan geopolitik dari dua belah pihak. Pada tahun 1990 dan pada tahun 2006 Cina menawarkan proses pengembangan sumber daya bersama di wilayah sekitar Kepualuan Diaoyu/ Senkaku, tetapi Jepang menolak. Tawaran itu diperbarui pada akhir 2010, tetapi Tokyo tidak melihat alasan untuk pengembangan bersama karena "klaim Cina terhadap Senkaku tidak memiliki dasar di bawah hukum dan sejarah internasional." Namun, dalam sengketa batas laut kedua negara, Cina dan Jepang mencapai sebuah perjanjian di tahun 2008 untuk bersama-sama mengembangkan deposit gas di ladang Chunxiao / Shirakaba, meskipun tidak banyak kemajuan dibuat sejak adanya perjanjian tersebut (Ivy Lee 2012).

Ketegangan mulai terasa sejak tahun 2010 antara Cina dan Jepang terkait deng sengketa kedua pihak di Kepulauan Diaoyu/Senkaku. Pada 7 September 2010, pukat nelayan Cina bertabrakan dengan dua kapal patroli Penjaga Pantai Jepang (Japan Coast Guard) di perairan dekat Kepulauan Senkaku. Tiga kapal patroli Jepang, Yonakuni, Mizuki dan Hateruma bertemu kapal pukat Cina, Minjinyu 5179, sekitar 12 kilometer barat laut Kepulauan Senkaku, dan memerintahkannya untuk berhenti dengan tujuan pemeriksaan. Kapal pukat Cina menolak, dan bertabrakan pertama dengan Yonakuni, dan kemudian dengan Mizuki, setelah pengejaran selama 40 menit. Para anggota Japan Coast Guard naik ke kapal, dan menahan kapten, Zhan Qixiong, dan krunya saat menyita pukat tersebut. Pemerintah Jepang memutuskan untuk memperlakukan insiden ini di bawah hukum domestik, dan untuk menuntut kapten Tiongkok atas kejahatan menghalangi JCG dalam menjalankan tugasnya (Smith 2011).

Pemerintah Cina langsung bereaksi. Sehari setelah kapal dan awaknya ditahan, Kementerian Luar Negeri Cina memanggil Duta Besar Jepang Niwa, dan menuntut pembebasan kapten, krunya, dan kapal pukat miliknnya. Sementara itu, JCG menyerahkan kapten nelayan Tiongkok kepada jaksa penuntut dengan kemungkinan dakwaan pada 10 September. Kementerian Luar Negeri Cina kemudian mengumumkan tanggapan pertamanya terhadap insiden tersebut - penangguhan negosiasi Laut Cina Timur. Tiga hari setelah insiden tersebut, Jepang melepaskan 14 awak beserta kapal pukat ke Cina. Pada 16 September, Menteri Pertanahan, Infrastruktur, Transportasi, dan Pariwisata Jepang Seiji, Maehara mengunjungi stasiun Penjaga Pantai Ishigaki untuk memeriksa kapal-kapal patroli Jepang yang rusak (Smith 2011).

Ketika Jepang terus menyelidiki insiden itu, pengadilan Ishigaki memperpanjang masa penahanan kapten Cina dari 20 September hingga 29 September. Reaksi Tiongkok menjadi lebih parah yang ditunjukan dengan penahan empat warga Jepang oeh Cina pada tanggal 20 
September atas tuduhan memasuki wilayah militer terbatas di Provinsi Hebei. Keempat orang Jepang itu adalah karyawan Fujita Corporation yang dikirim ke Cina sebagai bagian dari proyek Jepang untuk merebut kembali senjata kimia bekas Perang Dunia II yang ditinggalkan oleh Tentara Kekaisaran Jepang. Secara diplomatis, pemerintah Cina juga menolak untuk mempertimbangkan pertemuan Perdana Menteri Wen dan Perdana Menteri Naoto Kan di Majelis Umum PBB di New York. Pada pertemuan tersebut, Wen secara terbuka menuntut pembebasan kapten penangkapan ikan Tiongkok, dan juga dalam kesempatan lain di pertemuan pribadi orang Tiongkok-Amerika di New York, mereka berpendapat bahwa Cina harus mengambil "tindakan lebih lanjut" jika Jepang terus menahannya (Smith 2011).

Cina juga dilaporkan menggunakan instrumen ekonomi untuk memaksa Jepang melepaskan kaptennya. Pada tanggal 23 September, New York Times melaporkan bahwa China mengurangi ekspor tanah jarangnya ke Jepang. Jepang mengandalkan Cina untuk 82 persen dari bahan tanah jarangnya, yang digunakan dalam elektronik berteknologi tinggi, juga baterai, dan teknologi energi hijau (Ministry of Economy 2011). Meskipun pejabat pemerintah Cina menolak untuk mengakui embargo, pejabat bea cukai tampaknya dilarang menampung elemen tanah jarang di kapal di pelabuhan Cina. Ketegangan menjadi semakkin tinggi, ketika Jepang dan pembeli mineral Cina lainnya terlibat dalam ajudikasi World Trade Organization. Namun penggunaan instrumen ekonomi mendapatkan tekanan di tengah-tengah konfrontasi diplomatik yang kemudian mengubah secara dramatis persepsi global tentang penanganan Cina terhadap insiden tersebut.

Pada tanggal 24 September wakil jaksa di Ishigaki mengumumkan pembebasan kapten nelayan Tiongkok, yang menyatakan bahwa "dampak diplomatik" dari kasus ini menunjukkan gangguan proses hukum yang belum pernah terjadi sebelumnya. Keesokan harinya, diplomat Jepang diizinkan untuk bertemu dengan eksekutif Fujita Corporation di Beijing. Juru bicara Kementerian Luar Negeri Cina Jiang Yu meminta maaf kepada pemerintah Jepang, dan adanya kompensasi ke Cina untuk kerusakan yang terjadi. Namun. Perdana Menteri Jepang Kan menolak permintaan maaf ini, kemudian di hari berikutnya Kepala Sekretaris Kabinet Yoshito Sengoku menyarankan bahwa Cina yang perlu memberi kompensasi kepada Jepang untuk perbaikan kapal JCG. Dalam beberapa hari, Cina melepaskan tiga dari empat pengusaha Fujita Corporation yang ditahan di Cina, dan ada beberapa laporan yang belum dikonfirmasi mengenai relaksasi ekspor logam tanah jarang (Fackler 2010).

Ketegangan antara kedua negara muncul kembali ketika pada tahun 2012 sebuah laporan mulai beredar bahwa pemerintah Jepang berencana untuk membeli tiga pulau di Kepulauan Senkaku yaitu Uotsuri-jima, Kita-kojima dan Minami-kojima, dari seorang pengusaha swasta Saitama. Perdana Menteri Noda Yoshihiko mengkonfirmasi pembelian yang direncanakan pada Juli. Pada 9 September 2012, Presiden Hu Jintao bertemu dengan Perdana Menteri Noda di sela pertemuan KTT Kerjasama Ekonomi Asia-Pasifik regional di Vladivostok untuk membahas masalah tersebut. Hu mengeluarkan peringatan keras bahwa Cina dengan tegas menentang rencana pembelian tersebut dikarenakan Cina juga mengklaim Kepulauan Diaoyu sebagai miliknya. Keesokan harinya, pada 10 September, Kabinet Jepang menutup kesepakatan pembelian dengan kepemilikan pribadi sebesar 2,05 miliar yen (Ivy Lee 2012).

Namun, dampak dari adanya upaya pembelian tiga pulau di Kepulauan Diaoyu menimbulkan protes massal oleh masyarakat Tiongkok di 85 kota di seluruh Cina pada akhir pekan setelah pengumuman pembelian. Televisi menyiarkan gambar-gambar yang memperlihatkan polisi anti huru hara dan paramiliter Tiongkok, membentuk garis phalanx di sekitar kedutaan Jepang di Beijing untuk menahan gelombang masyarakat yang tampaknya berusaha menyerbu gedung. Toko-toko yang menjual barang-barang Jepang dan mobil-mobil Jepang dirusak (Ivy Lee 2012). 
Kementerian Luar Negeri Cina dengan cepat mengeluarkan pernyataannya pada hari yang sama, dengan menyatakan: "Terlepas dari representasi kuat yang berulang dari pihak Cina, pemerintah Jepang mengumumkan pada 10 September 2012 'pembelian' Pulau Diaoyu dan afiliasinya Nan Xiaodao dan Bei Xiaodao, hal ini gambarkan sebagai bentuk dari nasionalisasi pulau-pulau. Hal ini merupakan pelanggaran berat terhadap kedaulatan Cina atas wilayahnya sendiri dan sangat ofensif terhadap 1,3 miliar orang Tiongkok".

Cina kemudian mengambil sejumlah langkah untuk memperkuat klaimnya sendiri. Pada 13 September 2012, Perwakilan Permanen Tiongkok untuk PBB, Li Baodong, bertemu dengan Sekretaris Jenderal PBB Ban Ki-moon untuk mengarsipkan kepadanya salinan bagan maritim yang menguraikan laut teritorial Kepulauan Diaoyu dan pulau-pulau afiliasinya. Dengan bagan ini, Cina mengusulkan untuk menetapkan dasar terkait pengklaiman yurisdiksi nasional atas Zona Ekonomi Eksklusif dan landas kontinen sesuai dengan ketentuan Konvensi PBB tentang Hukum Laut (United Nations Convention on the Law of Sea).

Selanjutnya, enam kapal pengintai laut Cina dikirim ke Laut Cina Timur, yang disebut Cina sebagai "misi patroli dan penegakan hukum." Pada minggu-minggu berikutnya, kapal non-militer berpatroli di laut sekitar Kepulauan Diaoyu Dao / Senkaku. Dalam sebuah langkah baru yang bertujuan menegaskan kembali kepada komunitas internasional, kedaulatan Tiongkok atas Diaoyu Dao, Administrasi Kelautan Negara dan Kementerian Urusan Sipil pada tanggal 20 September 2012 merilis daftar nama standar untuk entitas geografis di Kepulauan Diaoyu dan 70 pulai dari pulau-pulau tersebut yang berafiliasi juga dengan letak garis bujur dan lintang, dan juga peta lokasi (Ivy Lee 2012).

Akhirnya, pada tanggal 26 September 2012, Pemerintah Tiongkok menerbitkan Buku Putih, bertuliskan " Diaoyu Dao, an Inherent Territory of China." Dalam Global Times, yang diterbitkan oleh People's Daily, berpendapat, "mundur bukanlah pilihan bagi China". 15 Republik Tiongkok (Republic of China ) merilis sebuah position paper pada 17 September 2012, bertuliskan "Ringkasan fakta historis tentang pendudukan rahasia dan ilegal Jepang di Kepulauan Diaoyutai." Position paper ini mirip dengan Buku Putih Republik Rakyat Tiongkok dalam argumennya untuk kedaulatan Kepualuan Diaoyu dan bukti historis yang identik. Kemudian pada tanggal 10 Oktober 2012, Republik Tiongkok juka menerbitkan satu halaman iklan penuh di New York Times terkait dengan klaim kedaulatannya dan menawarkan inisiatif untuk pengembangan bersama Laut Cina Timur (Ivy Lee 2012).

Pada tanggal 9 Januari 2006, Cina dan Jepang pernah melakukan joint development terkait dengan sengketa Kepulauan Diaoyu/Senkaku, dimana kedua pihak bersama - sama mengelolah kepualauan tersebut. Kesepakatan ini belum dinyatakan berhasil dikarenakan belum disepakati berapa investasi dari Cina dan Jepang dan juga pembagian keuntungan atas kepulauan Diaoyu/Senkaku. Selain itu, kesepakatan ini menimbulkan banyak protes dari masyarakat kedua negara, sehingga kesepakatan ini tidak berjalan. Ketegangan antara kedua negara masih ada, dikarenakan terlihat adanya patroli rutin yang dilakukan oleh masing masing negara di perairan sekitar Kepulauan Diaoyu/Senkaku ini.

\section{Kesimpulan dan Rekomendasi}

Dalam sengketa Kepulauan Diaoyu/Senkaku, Tiongkok dan Jepang memiiki klaim tersendiri dengan latar belakang sejarah yang berbeda-beda. Cina mengklaim atas dasar histori dari Dinasti Qing. Jepang menganggap daerah tersebut merupakan daerah yang disebut sebagai "terra nullius" sebuah istilah bahasa latin yang berasal dari hukum Romawi, yang berarti tanah yang tidak dimiliki oleh siapapun..

Secara adminstratif kepulauan tersebut telah dikuasi Jepang sejak tahun 1894. Dan pada tahun 1952 hingga 1972 Amerika Serikat mengelola kendali atas pulau tersebut pasca 
Perang Dunia 2. Setelah tahun 1972 melalui Perjanjian Reversi Okinawa, Amerika Serikat mengembalikan kendali pulau tersebut kepada Jepang dan tentu saja mendapat protes dari Cina.

Dengan adanya laporan bahwa Kepulauan Diaoyu/Senkaku memiliki banyak kandungan sumber daya alam, semakin membuat kedua negara berlomba - lomba untuk mendapatkan klaim atas kepulauan tersebut. Ketegangan politk terjadi antara kedua negara baik dilihat dengan adanya konflik - konflik kecil yang terjadi tetapi tidak sampai menimbulkan perang terbuka. Patroli laut terus dilakukan oleh kedua negara di sekitar perairan Kepulauan Diaoyu/Senkaku hingga saat ini.

Sebaiknya, kedua negara harus saling bernegosiasi dengan mencari jalan tengah bagaimana menyelesaikan sengketa tersebut, jika tidak menemukan solusi maka Cina dan Jepang bisa menghadirkan pihak ketiga yang berasal dari kawasan Asia Timur untuk membantu mereka, dan juga perlu adanya bantuan dari organisasi regional yang sanggup memberikan solusi yang tepat kepada kedua negara 


\section{DAFTAR PUSTAKA}

\section{Buku}

Agnew, John. 1987. Place \& Politics: The Geographical Mediation of State and Society . London: Unwin.

Petersen, Alexandros. 2011. The World Island: Eurasian Geopolitics and the Fate of the West . Santa Barbara: Praeger.

Sempa, Francis P. 2002. Geopolitics, From the Cold War to the 21 st Century. New Jersey: Transaction Publishers.

\section{Jurnal}

Ivy Lee, Fang Ming. 2012. "Deconstructing Japan's Claim of Sovereignty over the Diaoyu/Senkaku Island." The Asia-Pacific Journal 2-5.

Pan, Zhongqi. 2007. "Sino-Japanese Dispute over the Diaoyu /Senkaku Islands: "The Pending Controversy from the Chinese Perspective ." Journal of Chinese Political Science 12-71.

Smith, Sheila A. 2011. "Japan and the East China Sea Dispute." Contested Terrain: China's Periphery and International Relations in Asia. Washington, D.C: Foreign Policy Research Institute and the Reserve Officers. 370-390.

\section{Websites}

Fackler, Martin. 2010. Japan Rejects Apologizing to China. News Report, The New York Times.

Garlicki, Kasper M. 2014. The Senkaku/Diaoyu Island Dispute: History and Current Developments. Washington: Eurasia Center.

Jeffry, Handoyo El. 2012. Reformasi Ala Restorasi Meiji. Online News, Jakarta: Kompasiana.

Ministry of Economy, Trade, and Industry. 2011. "The Situation Regarding Rare Earth Elements."

Ministry of Foreign Affairs Japan. 2012. "Fact Sheet on the Senkaku Islands." 